\title{
The prophylactic effect of intravenous magnesium infusion on postoperative sore throat after thyroid surgery. A randomized clinical trial
}

\section{Efecto profiláctico de la infusión de magnesio en dolor de garganta postoperatorio luego de una tiroidectomía. Un ensayo clínico aleatorizado}

Raham Hasan Mostafa', Ashraf Nabil Saleh', Ibrahim Mohamed Ibrahim¹

\begin{abstract}
Background: The reported incidence of postoperative sore throat (POST) varies widely from 14.4 to $100 \%$ with maximum severity at $4^{\text {th }}$ to $6^{\text {th }}$ postoperative hour. Nonetheless, it has increasingly become a common clinical problem particularly in thyroid surgery. Although POST usually resolves spontaneously in few days, it is likely to be the most common complaint. Objectives: Driven by the increased number of patients with post-intubation sore throat following thyroid surgery, the aim of the present study was to evaluate the effectiveness of perioperative magnesium infusion in attenuating POST after thyroidectomy. Methods and Material: 80 female patients undergoing thyroid surgery, were preoperatively randomized into one of 2 groups. The magnesium group received magnesium sulfate $(30 \mathrm{mg} / \mathrm{kg})$ in $100 \mathrm{ml}$ of isotonic saline over $15 \mathrm{~min}$ before induction of anesthesia, followed by a continuous magnesium sulfate infusion $(10 \mathrm{mg} / \mathrm{kg} / \mathrm{h})$ for the duration of the operation. The control group received the same volume and rate of isotonic saline. Results: This study showed that perioperative magnesium infusion had significantly reduced the overall incidence and severity of POST. The incidence of POST at rest (patients who recorded non-zero POST score after thyroid surgery) in the control group was $75 \%$ while the incidence of POST in magnesium group was $37.5 \%$ which is lower and that was highly significance. Higher sedation scores were encoun-
\end{abstract}

Key words:

Magnesium, thyroidectomy, analgesia

Anesthesiology, Ain Shams University, Egypt.

Fecha de ingreso: 13 de noviembre de 2019

Fecha de aceptación: 20 de enero de 2020

ORCID

https://orcid.org/5370000-0002-5560-2733

Conflict of interest: None.

Source of Funding: None.

Correspondencia:

Raham Hasan Mostafa

Email: rahamhasan@yahoo.com 
tered on arrival to PACU in Magnesium group when compared to controls. Conclusions: We concluded that perioperative magnesium sulphate infusion effectively decreased overall POST incidence and severity after thyroidectomy with better hemodynamic stability, albeit higher risk of post operative sedation.

\section{RESUMEN}

La incidencia reportada de dolor de garganta postoperatorio (POST) varía ampliamente de 14,4 a $100 \%$ con severidad máxima en la $4^{\text {ta }}$ a $6^{\text {ta }}$ hora postoperatoria. Sin embargo, se ha convertido cada vez más en un problema clínico común, particularmente en la cirugía de tiroides. Aunque la POST generalmente se resuelve espontáneamente en pocos días, es probable que sea la queja más común. Objetivos: Impulsado por el mayor número de pacientes con dolor de garganta después de la intubación después de la cirugía de tiroides, el objetivo del presente estudio fue evaluar la efectividad de la infusión perioperatoria de magnesio para atenuar la POST después de la tiroidectomía. Métodos y Material: 80 pacientes mujeres sometidas a cirugía de tiroides, fueron asignadas al azar preoperatoriamente en uno de los 2 grupos. El grupo de magnesio recibió sulfato de magnesio ( $30 \mathrm{mg} / \mathrm{kg}$ ) en $100 \mathrm{ml}$ de solución salina isotónica durante 15 minutos antes de la inducción de la anestesia, seguido de una infusión continua de sulfato de magnesio (10 mg/kg/h) durante la operación. El grupo control recibió el mismo volumen y tasa de solución salina isotónica. Resultados: Este estudio mostró que la infusión perioperatoria de magnesio había reducido significativamente la incidencia general y la gravedad de la POST. La incidencia de POST en reposo (pacientes que registraron una puntuación POST distinta de cero después de la cirugía de tiroides) en el grupo de control fue del $75 \%$, mientras que la incidencia de POST en el grupo de magnesio fue del 37,5\%, que es menor y de gran importancia. Se encontraron puntajes de sedación más altos al llegar a la UCPA en el grupo Magnesio en comparación con los controles. Conclusiones: Llegamos a la conclusión de que la infusión perioperatoria de sulfato de magnesio disminuyó efectivamente la incidencia general de POST y la gravedad después de la tiroidectomía con una mejor estabilidad hemodinámica, aunque un mayor riesgo de sedación postoperatoria.

\author{
Palabras clave: \\ Magnesio, \\ tiroidectomía, \\ analgesia
}

\section{Introduction}

E ndotracheal intubation increases the probability of postoperative sore throat (POST) to 30$100 \%[1,2]$. Other alternatives as laryngeal and face mask ventilation reduce the incidence of POST, but tracheal intubation is mandatory sometimes $[3,4]$.

POST is common after thyroidectomy[5] due to manipulation of the trachea during positioning, dissection of the gland and the neck being hyperextended leading to injury of the tracheal mucosa and vocal folds[6].

Postoperative pain in thyroid surgeries is usually lower than other types of surgeries but the main complain lies in the continuing distress caused by POST[7].
Thus, searching for pharmacological and non-pharmacological ways to decrease POST might increase patient satisfaction after thyroidectomy surgeries.

Magnesium has a promising role in reducing POST by blocking N-methyl-D-aspartate (NMDA) receptors and inhibiting calcium influx to attain its antinociceptive and anti-inflammatory effect $[8,9]$. Previous studies on animals showed its ability to decrease the occurrence of POST[10] and other drugs like ketamine showed similar properties on POST[11,12].

We hypothesized that prophylactic administration of intravenous magnesium might be effective in reducing overall POST incidence. The aim of this prospective, randomized, double-blind study was to evaluate the prophylactic effect of intravenous mag- 
nesium sulphate on reducing POST in patients undergoing thyroid surgery.

\section{Subjects and Methods}

Study design and setting: This was a prospective, randomized, double-blinded study that was carried out in Ain Shams university hospital (ASUH).

Study population: The study comprised 80 patients who joined the study after informed written consents have been obtained from them. The work was approved by the Ethics committee of ASUHs (FMASU R56/2018) and in accordance with the ethical guidelines of the Declaration of Helsinki, 1975.

The study was prospectively registered with Pan African Clinical Trial Registry (PACTR) with Registration Number PACTR201810759555893 and was conducted in the period from November 2018 to February 2019.

Eligibility criteria for this study included: female patients, with a ranging age of 20 to 50 years old, American Society of Anesthesiologists physical status (ASA-PS) I-II, scheduled for total thyroidectomy due to simple multinodular goiter, under general anesthesia lasting for more than one hour.

Patients meeting any of the following conditions were excluded: surgery duration $>3$ hours, pre-existing sore throat, corticosteroid use or respiratory disease. Additional exclusion criteria were as follows: pregnancy or breast feeding; body mass index (BMI) $>-30 \mathrm{~kg} / \mathrm{m}^{2}$; heart block; heart failure; renal insufficiency; hyperkalemia; liver cell failure; psychiatric or neurological disorders and hypersensitivity to magnesium. It was very important to exclude any preoperative vocal cord abnormality using indirect laryngoscopy which if present, the patient was excluded.

Preoperative preparation: All patients were admitted to ASUH the day preceding surgery. A preoperative visit was held to discuss anesthesia technique, obtain history and check relevant investigations in addition to thyroid profile. Patients' baseline heart rate (HR) and mean arterial pressure (MAP) were recorded.

Patients' randomization, intraoperative interventions and management: 80 patients were preoperatively randomized into one of 2 groups (Magnesium group and Control group) by a computer-generated random numbers list together with the use of opaque sealed envelopes that was prepared by an anesthesiologist who was not part of the study. The magnesium group received a loading dose of magnesium sulphate $(30 \mathrm{mg} / \mathrm{kg}$ ) in $100 \mathrm{ml}$ of isotonic saline over $15 \mathrm{~min}$ before induction of anesthesia, followed by a maintenance dose as a continuous magnesium sulphate infusion $(10 \mathrm{mg} / \mathrm{kg} / \mathrm{h})$ for the duration of surgery untill the start of skin closure. The control group received the same volume of isotonic saline, administered in the same way as in the magnesium group. All solutions were prepared by an anesthesia nurse who was not involved in the study based on the patient's assigned group, handed it to the attending anesthesiologist who also had no role in patient's assessment. The syringe used in the infusion was labeled 'study drug' with no marks indicating group allocation. This dosing regimen followed current literature and guidelines[13].

Patients were preoxygenated with $10 \mathrm{~L} / \mathrm{min}$ $100 \% \mathrm{O}_{2}$ for 3-5 min. General anesthesia induction was achieved by means of standard agents. Propofol was first administered at a dose of $2 \mathrm{mg} / \mathrm{kg}$ followed by fentanyl at a dose of $1 \mu \mathrm{g} / \mathrm{kg}$ and endotracheal intubation was facilitated with atracurium $0.5 \mathrm{mg} / \mathrm{kg}$ as a neuromuscular blocker (NMB). Direct laryngoscopy was done using Macintosh laryngoscope blade size 3 or 4 (as per patient) by an experienced anesthesiologist with sterile reinforced oral cuffed endotracheal tube (ETT) (ULTRAMED ${ }^{\circledR}$, Abnob, Assiout, Egypt) of appropriate size (6.5 or $7 \mathrm{~mm}$ internal diameter (ID)). Application of external laryngeal pressure to assist endotracheal intubation was recorded. Intubating condition was assessed by the anesthesiologist who performed each intubation using "Cormack and Lehane classification". Grade 1 denotes: complete visualization of the vocal cords; grade 2 denotes: visualization of the inferior portion of the glottis; grade 3 denotes: visualization of only the epiglottis; grade 4 denotes: visualization of tongue and soft palate only. Patients with more than two attempts of intubation or those with blood-tinged endotracheal tube, after tracheal extubation, were excluded from this study.

After tracheal intubation and securing the ETT, controlled mechanical ventilation (CMV) was started. Bilateral equal air entry was confirmed by chest auscultation. For both groups, CMV was achieved by tidal volumes of $6-8 \mathrm{~mL} / \mathrm{kg}$ and respiratory rates of up to 12-14 breaths/min to maintain normocapnia. Auscultation of equality of air entry was done again after positioning and both eyes were secured. Appropriate care was taken during positioning and surgery to decrease movement of ETT within the trachea.

Anesthesia was maintained with isoflurane 1-2\% Minimum Alveolar Concentration (MAC) and atracurium $0.1 \mathrm{mg} / \mathrm{kg}$ given every 20 minutes using 1:1 oxygen/air mixture. Intraoperative monitoring included noninvasive blood pressure (BP), heart rate (HR), 
electrocardiogram, pulse oximetry and capnography. Patients' vital signs such as HR and MAP values were recorded preoperatively and every 15 minutes for 120 minutes following induction of anesthesia. A bolus dose of $25 \mu \mathrm{g}$ fentanyl was given as required to keep HR and MAP within $20 \%$ of their baseline values. In case of arterial hypotension (systolic blood pressure drop to $<80 \mathrm{mmHg}$ ): a bolus of $250 \mathrm{ml}$ normal saline was given intravenously. If still hypotensive; 6 mg ephedrine intravenously would be given. In case of bradycardia (HR drop to $<40$ beat $/ \mathrm{min}$ ); $0.5 \mathrm{mg}$ atropine was given intravenously. Intraoperative cumulative fentanyl consumption was recorded for each patient. During the hemostasis phase at the end of surgery, 1 gram paracetamol \& $30 \mathrm{mg}$ ketorolac were injected as intravenous infusion for postoperative analgesia. $4 \mathrm{mg}$ ondansetron was also injected as an antiemetic.

At the end of surgery, NMB was reversed with a combination of neostigmine $0.05 \mathrm{mg} / \mathrm{kg}$ intravenous (IV) and atropine $0.01 \mathrm{mg} / \mathrm{kg} \mathrm{IV}$. Gentle oral suctioning was done under direct vision then tracheal extubation was done after the return of spontaneous ventilation and patients following commands. The extubation time (from discontinuation of isoflurane to extubation) was recorded in minutes.

After transferal to the postoperative care unit (PACU), patients received $5 \mathrm{~L} / \mathrm{min} \mathrm{O}_{2}$ via face mask. Also, they were observed for any magnesium related side effects (respiratory depression, arterial hypotension, bradycardia or postoperative nausea and vomiting). In case of respiratory depression (respiratory rate $<8$ breaths/min): painful stimulation was done to arouse the patient together with increasing oxygen flow to $10 \mathrm{~L} / \mathrm{min}$ via face mask until the patient became alert with no respiratory depression or hypoxemia. In case of emesis: $10 \mathrm{mg}$ IV metoclopramide was prescribed for nausea and/or vomiting. In case of arterial hypotension or bradycardia, they were managed as planned intraoperatively.

It is well recognized that reporting of sore throat is affected by the method of questioning that is whether the questions asked directly or indirectly. That is because the expression of postoperative sore throat constitutes a variety of sign and symptoms. For example, sore throat can be expressed as pharyngitis, discomfort, laryngitis, tracheitis, hoarseness, cough or dysphagia[14]. In our study, we specifically asked about any of the following symptoms: pharyngitis, discomfort and/or laryngitis.

The incidence and grading of POST were evaluated at 0,6 and 24 hours after surgery. Overall incidence of POST was defined as the number of pa- tients who reported a sore throat grade of greater than 0 during the $24 \mathrm{~h}$-evaluation period. Sore throat was scored on a four-point scale (0-3)[15], where 0 $=$ no sore throat; $1=$ mild sore throat (complains of sore throat only on asking); $2=$ moderate sore throat (complains of sore throat on her own); and 3 $=$ severe sore throat (change in voice or hoarseness, in addition to throat pain). If present (score $\geq 1$ ); 8 mg dexamethasone would be given intravenously together with voice rest. Warm fluids, steam inhalation and oral lozenges were advised to be started whenever possible.

Ramsay sedation score (RSS) was recorded at specific timings: on arrival to PACU and after 1 and 2 hours from arrival to PACU for sedation assessment[16]. Ramsay sedation was scored on a six-point scale: 1 = Awake; Agitated or restless or both; $2=$ Awake; Cooperative, oriented, and tranquil; $3=$ Awake but responds to commands only; 4 = Asleep; brisk response to light glabellar tap or loud auditory stimulus; 5 = Asleep; sluggish response to light glabellar tap or loud auditory stimulus; 6 = Asleep; no response to glabellar tap or loud auditory stimulus.

The primary outcome of the current study was the incidence and severity of POST during the first 24 postoperative hours. Secondary outcomes were: intraoperative hemodynamic changes in addition to postoperative adverse effects and sedation level.

Sample size determination and statistical analysis: The required sample size was calculated using the Power Analysis and Sample Size $(0)$ software $\left(\right.$ PASS $^{\circ}$ ) version 15 (NCSS ${ }^{\odot}$, LLC. Kaysville, Utah, USA). Based on a previous study[2], the incidence of POST after thyroid surgery was expected to be approximately $78 \%$. We considered that an absolute reduction in the incidence of POST of $30 \%$ (i.e., from $78 \%$ to $48 \%$ ) would be a clinically relevant effect size for the present study. So, assuming an alpha error of 0.05 , we calculated that 40 patients per group would be required to achieve a power of $80 \%$ to detect a statistical significance for a difference of $30 \%$ in the incidence of POST.

Data were analyzed using IBMC SPSS ${ }^{\odot}$ Statistics version 23 (IBM ${ }^{\odot}$ Corp., Armonk, NY). Numerical variables were presented as mean and standard deviation (SD) and inter-group differences were compared using the unpaired t-test. Categorical variables were presented as ratio or as number and percentage and differences were compared using Fisher's exact test. Ordinal data were compared using the chi-squared test for trend. Mixed linear modeling was used to examine the effect of intervention (magnesium sulfate versus placebo) on the change in heart rate or mean 
arterial pressure over time. Two-sided P-values $<0.05$ were considered statistically significant.

\section{Results}

Study participants were 80 female patients divided into 2 groups, 40 each. The 2 groups were comparable with respect to age, BMI and ASA-PS. Also, number of intubation attempts, Cormack-Lehane score, ETT size and surgery duration were comparable between 2 groups (Table 1).

Regarding overall POST incidence, patients in Magnesium group had significantly lower incidence of sore throat when compared to those in Control group $(37.5 \%$ versus $75 \%$ respectively) ( $\mathrm{P}$-value = $0.001)$. Also, severity of POST was less in Magnesium group when compared to Control group (Table 2) (Figures 1 and 2). As shown in Table 3, use of magnesium sulphate was associated with a statistically significant reduction in the incidence of POST with a relative risk of $0.500(95 \% \mathrm{Cl}, 0.323$ to 0.775 ; P-value $<.001)$, absolute risk reduction of 0.375 and number

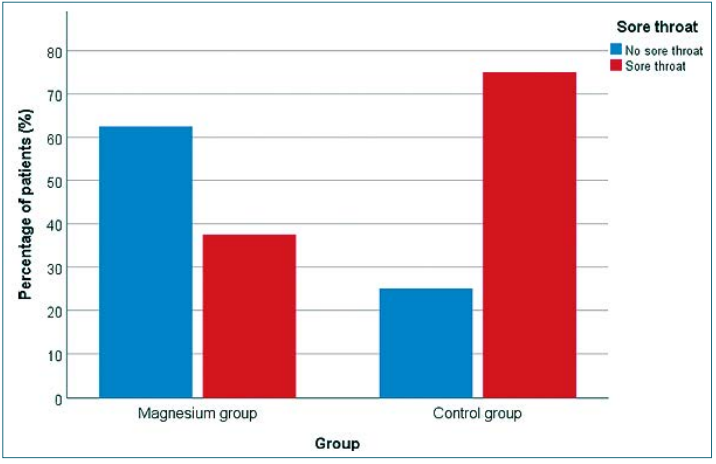

Figure 1. Incidence of sore throat in both study groups.

needed to treat of 2,667 (95\% Cl, 1,735 to 5,757).

Administration of magnesium sulphate has led to more intraoperative hemodynamic stability (lower HR and lower MAP) (Figures 3 and 4). We conducted a mixed linear modeling to compare the change in heart rate over time in both study groups which showed a statistically significant difference between the estimated marginal means of both groups (esti-

\begin{tabular}{|c|c|c|c|}
\hline Variable & Magnesium group $(n=40)$ & Control group $(n=40)$ & P-value* \\
\hline Age (years) & $35.6(11.0)$ & $34.1(10.0)$ & .525 \\
\hline ASA-PS (I/II) & $24 / 16$ & $28 / 12$ & $.482 \S$ \\
\hline $\mathrm{BMI}\left(\mathrm{kg} / \mathrm{m}^{2}\right)$ & $26.6(2.5)$ & $27.4(2.1)$ & .125 \\
\hline Frequency of intubation attempts & & & $.790 \S$ \\
\hline Single attempt & $32(80 \%)$ & $30(75 \%)$ & \\
\hline Two attempts & $8(20 \%)$ & $10(25 \%)$ & \\
\hline Application of ELP & $5(12.5 \%)$ & $5(12.5 \%)$ & $1.000 \S$ \\
\hline Cormack-Lehane grade & & & $1.000 \S$ \\
\hline Grade I & $22(55 \%)$ & $22(55 \%)$ & \\
\hline Grade II & $18(45 \%)$ & $18(45 \%)$ & \\
\hline Size of ETT & & & $1.000 \S$ \\
\hline ID $6.5 \mathrm{~mm}$ & $20(50 \%)$ & $20(50 \%)$ & \\
\hline ID $7.0 \mathrm{~mm}$ & $20(50 \%)$ & $20(50 \%)$ & \\
\hline $\begin{array}{l}\text { Cumulative fentanyl consumption } \\
(\mu \mathrm{g})\end{array}$ & $138.8(25.0)$ & $195.7(31.3)$ & $<.0001$ \\
\hline Operative time (min) & $134.6(12.7)$ & $140.1(17.4)$ & .110 \\
\hline Time to extubation (min) & $4.2(2.7)$ & $3.4(0.9)$ & .079 \\
\hline
\end{tabular}

Data are mean (standard deviation) or number (percentage); *. Unpaired t-test unless otherwise indicated; §. Fisher's exact test; P-value > 0.05 is considered statistically non-significant; ASA-PS = American society of anesthesiologist physical status; $\mathrm{BMI}=$ Body mass index; ELP = External laryngeal manipulation; ETT = Endotracheal tube; Group M = Magnesium group; Group $C=$ Control group; ID = Internal diameter. 
Table 2. Incidence of sore throat and other adverse outcomes in both study groups

\begin{tabular}{|c|c|c|c|}
\hline Variable & Magnesium group $(n=40)$ & Control group $(n=40)$ & P-value* \\
\hline Incidence of sore throat & $15(37.5 \%)$ & $30(75 \%)$ & .001 \\
\hline Severity of sore throat & & & $.004 \S$ \\
\hline None & $25(62.5 \%)$ & $10(25.0 \%)$ & \\
\hline Mild & $8(20.0 \%)$ & $14(35.0 \%)$ & \\
\hline Moderate & $4(10.0 \%)$ & $11(27.5 \%)$ & \\
\hline Severe & $3(7.5 \%)$ & $5(12.5 \%)$ & \\
\hline Incidence of PONV & $8(20.0 \%)$ & $10(25.0 \%)$ & .790 \\
\hline Over-sedation (RSS $\geq 3$ ) & $26(65.0 \%)$ & $0(0.0 \%)$ & $<.0001$ \\
\hline
\end{tabular}

Data are number (percentage); *. Fisher's exact test unless otherwise indicated; §. Chi-squared test for trend; PONV = Postoperative nausea and vomiting; RSS = Ramsay sedation score.

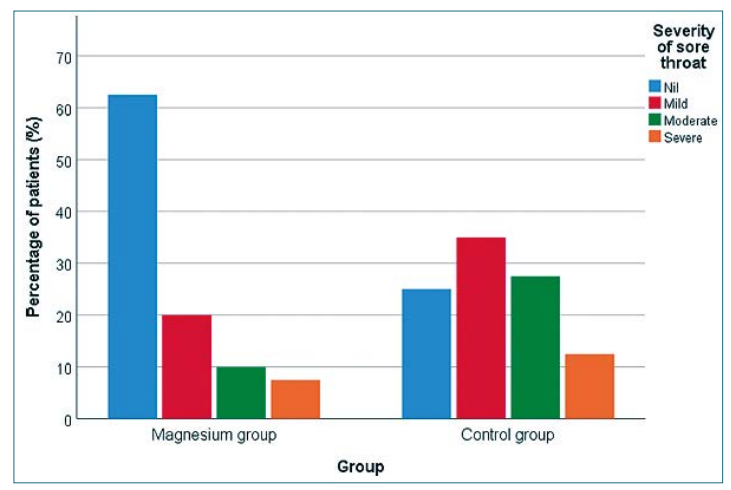

Figure 2. Severity of sore throat in both study groups.

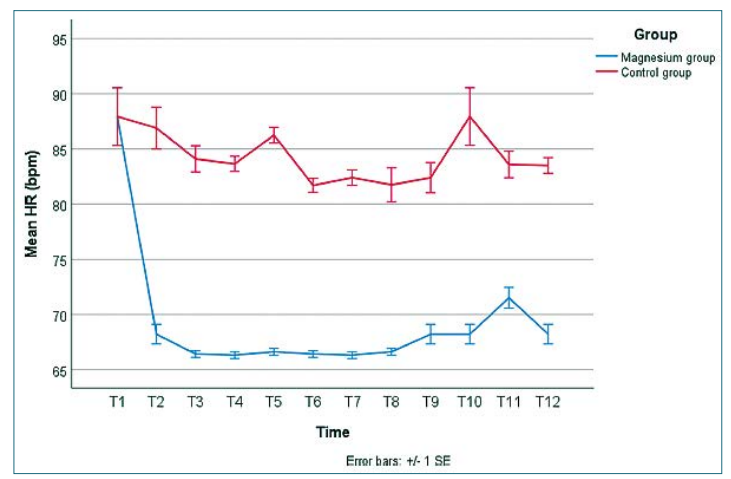

Figure 3. Change in mean heart rate (HR) in both study groups. Error bars represent the standard error (SE). T1 = baseline measurement, $\mathrm{T} 2=15$ minutes after intubation, T3 = 30 minutes after intubation, $\mathrm{T} 4=45$ minutes after intubation, T5 $=60$ minutes after intubation, T6 $=75$ minutes after intubation, T7 = 90 minutes after intubation, T8 $=105$ minutes after intubation, T9 $=120$ minutes after intubation, $\mathrm{T} 10=$ On arrival to PACU, T11 $=30$ minutes after arrival to PACU, T12 $=60$ minutes after arrival to PACU. mated marginal mean $\pm \mathrm{SE}, 68.5 \pm 0.5$ beat per minute (bpm) versus $85.1 \pm 0.5 \mathrm{bpm}$ for the Magnesium group or Control group, respectively) with a mean difference of $-16.6 \mathrm{bpm}$ and SE of the mean difference of $0.2 \mathrm{bpm}$ (P-value $<0.001)$. Also, We constructed another mixed linear model to compare the change in mean arterial blood pressure over time in both study groups which showed a statistically significant difference between the estimated marginal means of both groups (estimated marginal mean $\pm \mathrm{SE}, 68.8 \pm 0.4$ $\mathrm{mmHg}$ versus $93.3 \pm 0.4 \mathrm{mmHg}$ for the Magnesium group or Control group, respectively) with a mean difference of $-24.4 \mathrm{mmHg}$ and SE of the mean difference of $0.4 \mathrm{mmHg}$ (P-value $<0.001$ ) (Figure 3,4).

Also, we have noticed less intraoperative fentanyl consumption: $138.8 \pm 25 \mu \mathrm{g}$ fentanyl in Magnesium group versus $195.7 \pm 31.3 \mu \mathrm{g}$ fentanyl in Control group (P-value < 0.0001) (Table 1).

Tracheal extubation time was slightly prolonged in Magnesium group (mean of $4.2 \pm 2.7$ minutes) when compared with Control group (mean of $3.4 \pm$ 0.9 minutes) but was not statistically significant ( $\mathrm{P}$ value $=0.079)($ Table 1$)$. Additionally, postoperative nausea and vomiting (PONV) incidence was comparable between both groups in PACU $(\mathrm{P}$-value $=0.790)$ (Table 2).

Finally, higher sedation scores (RSS $\geq 3$ ) were encountered on arrival to PACU in Magnesium group when compared to Control group (P-value $<0.0001$ ) (Table 2).

\section{Discussion}

The increased number of patients developing POST following thyroid surgery, made us seek to eval- 


\section{Table 3. Risk analysis for the incidence of sore throat}

\begin{tabular}{lc}
\hline Risk index & Value \\
Risk of sore throat in magnesium group & 0.375 \\
Risk of sore throat in control group & 0.750 \\
Relative risk $(95 \% \mathrm{Cl})$ & $0.500(0.323$ to 0.775$)$ \\
Z-statistic & 3.100 \\
P-value* & .002 \\
Absolute risk reduction & 0.375 \\
Number needed to treat $(95 \% \mathrm{Cl})$ & $2.667(1.735$ to 5.757) \\
\hline
\end{tabular}

*. Z-test.

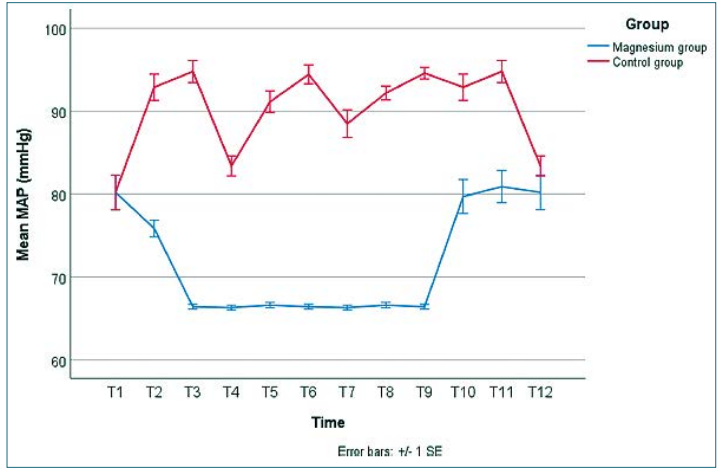

Figure 4. Change in mean arterial pressure (MAP) in both study groups. Error bars represent the standard error (SE). T1 = baseline measurement, $\mathrm{T} 2=15$ minutes after intubation, $\mathrm{T} 3=30$ minutes after intubation, $\mathrm{T} 4=45$ minutes after intubation, $\mathrm{T} 5=60$ minutes after intubation, $\mathrm{T} 6=75$ minutes after intubation, T7 = 90 minutes after intubation, T8 = 105 minutes after intubation, T9 $=120$ minutes after intubation, $\mathrm{T} 10=$ On arrival to PACU, T11 $=30$ minutes after arrival to PACU, T12 $=60$ minutes after arrival to PACU.

uate the effectiveness of perioperative magnesium sulphate infusion in attenuating POST after thyroidectomy. This study showed that, infusing magnesium sulphate with a loading dose of $30 \mathrm{mg} / \mathrm{kg}$ before anesthesia induction followed by $10 \mathrm{mg} / \mathrm{kg} / \mathrm{h}$ until the end of surgery, had significantly reduced the incidence of POST in the resting state after thyroid surgery. Also, severity of POST was less in the Magnesium group when compared to controls. This was in accordance with previous studies that proved intravenous magnesium sulphate efficacy in reducing incidence and severity of POST whether after lumbar surgery[13],[20] or functional endoscopic sinus surgery (FESS)[25]. No studies have been done on POST after thyroidectomy. In Park's study[13] for example, the overall incidence of POST after spinal surgery, which was assessed serially over $48 \mathrm{~h}$ postoperatively, was $50.7 \%$ in magnesium group. They used a loading dose of $30 \mathrm{mg} / \mathrm{kg}$ followed by a maintenance dose of $10 \mathrm{mg} / \mathrm{kg} / \mathrm{h}$ untill skin closure. Also, In Sheikh's study[20], also in spine surgey, the incidence of POST at all study stages was less in patients receiving magnesium sulphate than those receiving placebo. Patients receiving magnesium sulphate had less severe sore throat (mild) than those receiving placebo (moderate). Noteworthy, that in Sheikh's study, magnesium was given as a single dose of $40 \mathrm{mg} / \mathrm{kg}$ over 10 minutes after intubation with no maintenance dose. Finally, in a study done on POST severity after FESS surgery[25], Mohtadi reported mild POST at all examined time points $(0,30 \mathrm{~min}, 2$ hours, 24 hours after tracheal extubation) when compared to a control group. They used a single intravenous magnesium sulphate dose of $40 \mathrm{mg} / \mathrm{kg}$ over 20 minutes after intubation with no maintenance dose.

The prevalence of POST varies widely from 14.4 to $100 \%$ with maximum severity at $4^{\text {th }}$ to $6^{\text {th }}$ postoperative hour due to the gradually developing local inflammation[17,18]. It appeared that the ETT movement at the time of positioning and manipulation of the thyroid gland during surgery may be responsible. POST is more common in females, which can be attributed to their smaller diameter of trachea and softer mucosal wall[5]. Also, larger size of ETT ( $\geq 7.5 \mathrm{~mm}$ ID), more extensive surgery, older age (> 35 years) and prolonged surgeries (> 60 minutes) are nowadays considered the main contributing factors for the occurrence of POST[7]. And since postoperative pain after thyroidectomy is usually lower than that after major surgery, prevention of POST is of great concern in terms of improving postoperative patient's satisfaction[19]. Measures used to prevent POST after thyroid surgery include: the use of small sized ETT with careful patient positioning to decrease movement of the 
ETT within the airway.

Despite taking care during tracheal intubation, POST still happens[5]. It has been described as one of the most undesirable outcomes during the postoperative period, because it adversely affects patient satisfaction and activities after discharge from the hospital[2]. Since POST is attributed to an inflammatory response caused by airway mucosal trauma or tissue damage and is a sort of postoperative pain, pharmacologic agents possessing anti-inflammatory and anti-nociceptive properties would be beneficial in preventing and treating POST. Magnesium sulphate, an N-methyl-D-aspartate (NMDA) receptor antagonist, has potential advantage to play a beneficial role in reducing POST through its anti-nociceptive and anti-inflammatory effects[20].

Magnesium sulphate's analgesic action is mediated by non-competitive inhibition of NMDA receptor, blocking ion channels in a voltage-dependent manner. Magnesium sulphate reduces C-fibres activation through inhibition of the slow excitatory postsynaptic currents produced by NMDA receptor activation. NMDA receptor antagonists prevent calcium and sodium entry into the cells leading to central sensitization and wind-up as a result of peripheral nociceptive stimulation. They prevent hypersensitization by blocking NDMA receptor (located in the dorsal horn) activation by excitatory transmitters, like glutamate, and aspartate[21]. On the other hand, Magnesium sulphate exerts its anti-inflammatory effect by decreasing the release of inflammatory mediators such as histamine, thromboxanes, and leukotriens; therefore, it may be beneficial in controlling inflammation[22]. In a study done by Aryana et al.[23], they found that magnesium sulphate with a loading dose of $30 \mathrm{mg} / \mathrm{kg}$ followed by a maintenance dose of $10 \mathrm{mg} / \mathrm{kg} / \mathrm{h}$ had suppressed part of the inflammatory response after coronary artery bypass graft (CABG) surgery with cardiopulmonary bypass. They demonstrated a decrease in serum levels of Interleukin-6 and Tumour Necrosis Factor alpha postoperatively.

Interestingly, various routes of magnesium sulphate administration have been shown to effectively control POST (when compared with non-analgesic controls) given that NMDA receptors exist both centrally and peripherally. Topical magnesium sulphate, can be applied as a single dose prior to surgery whether in the form of nebulization, gargle or lozenges. Topical dose of magnesium sulphate can be fixed as $(100 \mathrm{mg}, 225 \mathrm{mg}, 250 \mathrm{mg}$ and $500 \mathrm{mg}$ ) or titrated according to patient body weight $(20 \mathrm{mg} / \mathrm{kg}$ ). But still, the safety of topical magnesium sulphate needs to be determined in further studies[24]. Also, not all patients can tolerate nebulized medications due to bitter taste of drugs or the need of cooperation of the patient to receive the full dose of nebulized medication without its leakage.

In our study, magnesium sulphate showed intraoperative hemodynamic stability with lower intraoperative fentanyl consumption and that goes with previous studies which reported the same findings[13],[26],[27]. Finally, the only postoperative complication reported was sedation at arriving to PACU, that soon disappeared at the following examined timings. And that comes in accordance with Kim's study[26] they have been rarely evaluated with respect to recovery quality under the same conditions. We compared the quality of recovery 40 (QoR-40 who showed more sedation in magnesium group early in PACU.

\section{Limitations}

The drawbacks of our study were the absence of recording of other magnesium- related adverse effects specifically: quality of NMB using train of four monitoring and serum magnesium levels. Secondly, the scale used to assess POST was a subjective scale and may be associated with bias. Additionally, some patients could interpret thyroidectomy incisional pain as sore throat in spite of clearly defining sore throat to them. This may arouse the importance of preoperative bilateral superficial cervical block in eliminating incisional pain and so decrease the incidence of POST misinterpretation. Thirdly, we didn't use bispectral index to monitor the depth of anesthesia. Fourthly, tracheal cuff pressure was not measured in this study and high cuff pressures are considered to be a contributing factor to the occurrence of sore throat through causing mucosal ischemia. Finally, comparison with other intravenous medications that had proved its efficacy in decreasing POST would be very valuable.

\section{Conclusion}

Perioperative magnesium sulphate infusion effectively decreased overall POST incidence and severity after thyroidectomy with better hemodynamic stability, at the expense of more post operative sedation. We suggest future research overcoming aforementioned limitations for better clarification of magnesium sulfate's potential beneficial effects. 


\section{References}

1. Combes X, Schauvliege F, Peyrouset O, Motamed C, Kirov K, Dhonneur $G$, et al. Intracuff Pressure and Tracheal Morbiditylnfluence of Filling Cuff with Saline during Nitrous Oxide Anesthesia. Anesthesiology. Anesthesiology. 2001 Nov;95(5):1120-4. https:// doi.org/10.1097/00000542200111000-00015 PMID:11684980

2. Lee JH, Lee HK, Chun NH, So Y, Lim CY. The prophylactic effects of gabapentin on postoperative sore throat after thyroid surgery. Korean J Anesthesiol. 2013 Feb;64(2):138-42. https://doi. org/10.4097/kjae.2013.64.2.138 PMID:23459631

3. Brimacombe J. The advantages of the LMA over the tracheal tube or facemask: a metaanalysis. Can J Anaesth. 1995 Nov;42(11):1017-23. https:// doi.org/10.1007/BF03011075 PMID:8590490

4. Joshi GP, Inagaki Y, White PF, Taylor-Kennedy L, Wat LI, Gevirtz $C$, et al. Use of the laryngeal mask airway as an alternative to the tracheal tube during ambulatory anesthesia. Anesth Analg. 1997 Sep;85(3):573-7. https:// doi.org/10.1213/00000539199709000-00016 PMID:9296411

5. Hisham AN, Roshilla $\mathrm{H}$, Amri N, Aina EN. Post-thyroidectomy sore throat following endotracheal intubation. ANZ J Surg. $2001 \mathrm{Nov}$; 71(11):66971. https://doi.org/10.1046/ j.1445-1433.2001.02230.x PMID:11736830

6. Edomwonyi NP, Ekwere IT, Omo E, Rupasinghe A. Postoperative throat complications after tracheal intubation. Ann Afr Med. 2006 Jan;5(1):28-32.

7. Kadri IA, Khanzada TW, Samad A, Memon W. Post-thyroidec- tomy sore throat: a common problem. Pak J Med Sci. 2009 Apr;25(3):408-12.

8. Koinig $\mathrm{H}$, Wallner $\mathrm{T}$, Marhofer $P$, Andel H, Hörauf K, Mayer $\mathrm{N}$. Magnesium sulfate reduces intra- and postoperative analgesic requirements. Anesth Analg. 1998 Jul;87(1):206-10. PMID:9661575

9. Tramer MR, Schneider J, Marti RA, Rifat K. Role of magnesium sulphate in postoperative analgesia. Anesthesiology. Anesthesiology. 1996 Feb;84(2):340-7. https://doi. org/10.1097/00000542199602000-00011 PMID:8602664

10. Zhu MM, Zhou QH, Zhu MH, Rong HB, Xu YM, Qian YN, et al. Effects of nebulized ketamine on allergen-induced airway hyperresponsiveness and inflammation in actively sensitized Brown-Norway rats. J Inflamm (Lond). 2007 May;4(1):10. https://doi.org/10.1186/14769255-4-10 PMID:17480224

11. Canbay O, Celebi N, Sahin A, Celiker V, Ozgen S, Aypar U. Ketamine gargle for attenuating postoperative sore throat. British journal of anesthesia. $2008 \mathrm{Mar}$ 1;100(4):490-3. https://doi. org/10.1093/bja/aen023.

12. Shrestha SK, Bhattarai B, Singh J. Ketamine gargling and postoperative sore throat. JNMA J Nepal Med Assoc. 2010 Oct-Dec;50(180):282-5. https:// doi.org/10.31729/jnma.55 PMID:22049891

13. Park JH, Shim JK, Song JW, Jang J, Kim JH, Kwak YL. A randomized, double-blind, noninferiority trial of magnesium sulphate versus dexamethasone for prevention of postoperative sore throat after lumbar spinal surgery in the prone position. Int J Med Sci. 2015 Sep;12(10):797-804. https:// doi.org/10.7150/ijms. 12831

PMID:26516308

14. Gemechu BM, Gebremedhn EG, Melkie TB. Risk factors for postoperative throat pain after general anaesthesia with endotracheal intubation at the University of Gondar Teaching Hospital, Northwest Ethiopia, 2014. Pan Afr Med J. 2017 Jun;27:127. https://doi.org/10.11604/ pamj.2017.27.127.10566 PMID:28904657

15. Thoppil JV, Imanual SR. Efficacy of ketamine gargle for attenuating postoperative sore throat in patients undergoing general anesthesia with endotracheal intubation. J Evol Med Dent Sci. 2017 Oct;6(81):5707-12. https://doi.org/10.14260/jemds/2017/1238.

16. Ramsay MA, Savege TM, Simpson BR, Goodwin R. Controlled sedation with alphaxalone-alphadolone. BMJ. 1974 Jun;2(5920):656-9. https:// doi.org/10.1136/bmj.2.5920.656 PMID:4835444

17. Mostafa RH, Saleh AN, Hussein MM. A Comparative Study of Three Nebulized Medications for the Prevention of Postoperative Sore Throat in the Pediatric Population. The Open Anesthesia Journal. 2018 Dec;12(1):85-93. https://doi.org/10.2174/2589645 801812010085.

18. Ashwini $H$, Kumari KS, Lavanya R. Comparative study of dexamethasone nebulisation with magnesium sulphate nebulisation in preventing post operative sore throat following endotracheal intubation. Indian Journal of Clinical Anesthesia. 2018;5(3):341-7. https://doi.org/10.18231/23944994.2018.0065.

19. Yang $C$, Jung SM, Bae YK, Park SJ. The effect of ketorolac and dexamethasone on the incidence of sore throat in women after 
thyroidectomy: a prospective double-blinded randomized trial. Korean J Anesthesiol. 2017 Feb;70(1):64-71. https://doi. org/10.4097/kjae.2017.70.1.64 PMID:28184269

20. Sheikh SA, Mir AH, Yousuf A, Naqash IA. Evaluation of efficacy of intravenous magnesium sulphate versus dexamethasone for prevention of postoperative sore throat in patients undergoing lumbar spine surgery in prone position: a prospective randomized double blind placebo controlled study. Int J Adv Med. 2019;6(3):833. https:// doi.org/10.18203/2349-3933. ijam20192248.

21. Chattopadhyay S, Das A, Nandy S. RoyBasunia S, Mitra T, Halder PS, Chhaule S, Mandal SK. Postoperative sore throat prevention in ambulatory surgery: A comparison between preoperative aspirin and magnesium sulphate gargle-a prospective, randomized, double-blind study. Anesth Essays Res. 2017 Jan; 11(1):94. https://doi. org/10.4103/0259-1162.186602 PMID:28298764

22. Borazan H, Kececioglu A, Okesli S, Otelcioglu S. Oral magnesium lozenge reduces postoperative sore throat: a randomized, prospective, placebo-controlled study. Anesthesiology. 2012 Sep;117(3):512-8. https://doi.org/10.1097/ ALN.0b013e3182639d5f PMID:22797283

23. Aryana P, Rajaei S, Bagheri A, Karimi F, Dabbagh A. Acute effect of intravenous administration of magnesium sulphate on serum levels of interleukin- 6 and tumor necrosis factor- $\alpha$ in patients undergoing elective coronary bypass graft with cardiopulmonary bypass. Anesth Pain Med. 2014 Jun;4(3):e16316. https://doi.org/10.5812/ aapm.16316 PMID:25237633

24. Kuriyama A, Maeda H, Sun R. Topical application of magnesium to prevent intubation-related sore throat in adult surgical patients: a systematic review and meta-analysis. Canadian Journal of Anesthesia/Journal canadien d'anesthésie. 2019 May 22:1-3. https://doi.org/10.1007/s12630019-01396-7.

25. Mohtadi A, Ghomeishi A, Behaeen K, Nesioonpour S, Shaffaf MR. Role of Magnesium Sulphate in the Prevention of Post-extubation Sore Throat in. Patients Undergoing Endoscopic Sinus Surgery. AMBIENT SCIENCE. 2018 Jan 1;5.

26. $\operatorname{Kim} M H, K i m$ MS, Lee $J H, K i m$ ST, Lee JR. Intravenously administered lidocaine and magnesium during thyroid surgery in female patients for better quality of recovery after anesthesia. Anesth Analg. 2018 Sep;127(3):63541. https://doi.org/10.1213/ ANE.0000000000002797 PMID:29324495

27. Sane $S$, Mahoori A. ValizadeHasanloei MA, Karami N, Dehgani $E$. The effect of intravenous magnesium sulphate on post operative sore throat in patients undergoing lumbar laminectomy. Anesthesiology and Pain. 2017 Jan;7(4):11-8. 